\title{
FREEDOM OF LAWYERS TO PROVIDE SERVICES UNDER DIRECTIVE 77/2491
}

\author{
Michael Siman \\ Faculty of Law, Pan-European University in Bratislava
}

\begin{abstract}
The following article deals with one of the different forms of free movement of lawyers in the EU, i.e. the freedom to provide services on a temporary basis. The relevant primary law alongside the applicable legislation, as interpreted by the Court in its case-law, is analysed. Special attention is paid to certain peculiarities of cross-border provision of services by lawyers, in particular the respect of rules of professional conduct.
\end{abstract}

Key words: European Union, Free Movement of Lawyers, Freedom to Provide Services, Directive 77/249, Rules of Professional Conduct

\section{INTRODUCTION}

The legal profession in the European Union plays a peculiar role in the context of achieving a true European market where free movement of professionals is guaranteed. The 'hall of fame' of the Court's case-law includes a wide array of names of lawyers that ring a bell with anyone familiar with EU law: Reyners, van Binsbergen, Thieffry, Klopp, Vlassopoulou, Morgenbesser and many others. It is quite logical that lawyers, given their legal erudition, were among the first professionals to invoke their rights under the Treaty. In a culture characterised by 'taking rights seriously'2, it is, beyond doubt, for lawyers to claim the guarantees offered by EU law not only on behalf of their clients, but also, a fortiori, on their own behalf. Indeed, the Court proved to be favourable to such endeavours. Despite the absence of relevant secondary legislation, it did not hesitate to declare the Treaty provisions granting the rights to free movement to European professionals, including lawyers, directly applicable.

The following article deals with one of the different forms of free movement of lawyers in the EU, i.e. the freedom to provide services on a temporary basis. The relevant primary law alongside the applicable legislation, as interpreted by the Court in its case-law, is analysed.

With respect to the freedom to provide services and the relevant primary and secondary law, besides the scope of application and the purpose of the applicable EU rules, special attention is paid to certain peculiarities of cross-border provision of services by lawyers, in particular the respect of rules of professional conduct in two Member States and the duty of a migrant lawyer to work in conjunction with a local lawyer.

1 This work was supported by the Slovak Research and Development Agency under the contract No. APVV-14-0893 (Free movement of persons and recognition of qualifications in the European Union and Slovak Republic).

2 Cf. DWORKIN, R. Taking rights seriously. Cambridge Mass. : Harvard University Press, 1978. 


\section{PURPOSE AND SCOPE OF APPLICATION}

Council Directive 77/249/EEC of 22 March 1977 to facilitate the effective exercise by lawyers of freedom to provide services, ${ }^{3}$ which deals only with measures to facilitate the effective pursuit of the activities of lawyers by way of provision of services and recognises the need to adopt more detailed measures to facilitate the effective exercise of the right of establishment, constituted a major step towards achieving the free movement of lawyers in the EU. As clearly stated by the Community legislature, that directive solely concerns provision of services and does not contain provisions on the mutual recognition of diplomas. In fact, Directive 77/249 is based on mutual recognition of national authorisations for lawyers issued by their home Member States.

S. Claessens observes that the fact that there seems to be a complete mutual recognition of lawyers who provide services in other Member States is actually most striking about that directive, which was, beyond doubt, very liberal for its time. ${ }^{4}$ The Council of Bars and Law Societies of the European Union (CCBE) also points out that the combination of Directives 77/249 and 98/5 has created a 'simple, non-bureaucratic and very liberal' system, which has led to easy cross-border mobility for lawyers and allowed them to reach a level of free movement in the EU, which is inconceivable in other parts of the world, even in the framework of federal structures, including the USA. At the same time, the special regime applicable to lawyers is 'far in advance of the structures which exist for other liberal professions in the EU' ${ }^{5}$ The Maastricht University/Panteia Study also shows that, thanks to Directive $77 / 249$, 'cross-border provision of services has become a common, largely unproblematic practice in the legal sector in the EU'.

It should be observed that the original proposal of Directive $77 / 249$ dates back to 1969 . However, at that time, it was rejected because certain Member States claimed that the profession of lawyer was subject to the derogation concerning official authority. In this respect, the Court's rulings in Reyners $^{7}$ and van Binsbergen ${ }^{8}$ opened the door to adopting such a measure of Community law.

Even though Directive 77/249 was adopted in the context of vertical harmonisation, no minimum criteria for education of lawyers were laid down, because such harmonisation would be impossible. Therefore, similarly to the Architects Directive, ${ }^{9}$ no educational standards were imposed with respect to lawyers, but, unlike in the case of architects, only the freedom to provide services (and not the freedom of establishment) was covered by the measure in question. ${ }^{10}$

With respect to Directive 2006/123/EC of the European Parliament and of the Council of 12 December 2006 on services in the internal market, ${ }^{11}$ it must be emphasised that, as stated in recital 88

\section{OJ 1977 L 78, p. 17.}

See CLAESSENS, S. Free Movement of Lawyers in the European Union. Nijmegen : Wolf Legal Publishers, 2008 , p. 28. CCBE position, Evaluation of the Lawyers' Directives, pp. 1 - 3. Available at <http://ccbe.eu/fileadmin/ speciality_distribution/public/documents/FREE_MOVEMENT_OF_LAWYERS/FML_Position_papers/EN_FML_20140912_CCBE_ position_on_Evaluation_of_the_Lawyers_Directives.pdf >. [q. 2018-05-29].

6 CLAESSENS, S. et al. Evaluation of the Legal Framework for the Free Movement of Lawyers, Final Report. Zoetermeer : Maastricht University/Panteia, 2012 (Maastricht University/Panteia Study), p. 230.

7 Judgment of 21 June 1974, Reyners, 2-74, EU:C:1974:68.

8 Judgment of 3 December 1974, van Binsbergen, 33-74, EU:C:1974:1299.

9 Council Directive 85/384/EEC of 10 June 1985 on the mutual recognition of diplomas, certificates and other evidence of formal qualifications in architecture, including measures to facilitate the effective exercise of the right of establishment and freedom to provide services (OJ 1985 L 223, p. 15).

10 See CLAESSENS, S. Free Movement of Lawyers in the European Union. Nijmegen : Wolf Legal Publishers, 2008 , p. 26.

11 OJ 2006 L 376, p. 36. 
of that directive, the provision on the freedom to provide services should not apply in cases where, in conformity with EU law, an activity is reserved in a Member State to a particular profession, for example requirements which reserve the provision of legal advice to lawyers. Accordingly, Article 16 of that directive, which enshrines the freedom to provide services, does not apply to matters covered by Directive 77/249. ${ }^{12}$ However, it seems that not all legal services are exempted from Directive $2006 / 123$ and on a more general level, it may be concluded that this directive applies also to those matters related to the provision of services by lawyers that are not covered by Directive 77/249. It follows that if an issue is not governed by Directive 77/249, other provisions of Directive 2006/123 than Article 16 (e.g. Article 24 on commercial communications by the regulated professions) will apply even in the case of services provided by lawyers. ${ }^{13}$

Article 1(1) of Directive 77/249 states that this directive applies, within the limits and under the conditions laid down therein, to the activities of lawyers pursued by way of provision of services. However, Member States may reserve to prescribed categories of lawyers the preparation of formal documents for obtaining title to administer estates of deceased persons, and the drafting of formal documents creating or transferring interests in land.

As confirmed by the Court, that derogation does not cover, in general terms, the various categories of legal professions, with the result that Member States would have the right, relying on that provision, to limit the pursuit of the activity of drafting formal documents for the creation or transfer of rights to property to certain categories of legal professionals - such as notaries - and thus to prohibit foreign lawyers from exercising the activities in question within the territory of those Member States. By contrast, that provision provides for a derogation with a more limited scope aimed specifically at certain prescribed categories of lawyers, which are, moreover, explicitly identified in that directive. In particular, the purpose of that derogation was to prevent lawyers from other Member States from pursuing the activities concerned in the United Kingdom or in Ireland. ${ }^{14}$

Any person listed in paragraph 2 of Article 1 of Directive 77/249 must be recognised by each Member State as a lawyer for the purpose of pursuing those activities. Any such lawyer must adopt the professional title used in the Member State from which he comes, expressed in the language or one of the languages, of that State, with an indication of the professional organisation by which he is authorised to practise or the court of law before which he is entitled to practise pursuant to the laws of that State. The competent authority of the host Member State may request the person providing the services to establish his qualifications as a lawyer. ${ }^{15}$

It follows that the automatic recognition of lawyers in the $\mathrm{EU}$ is based on mutual trust between the Member States. The host Member State cannot question the qualification of the lawyer concerned provided that the lawyer is recognised as such in the Member State from which he comes. Given the fact that the lawyer must provide services under the professional title of his home Member State, he can be easily identified as a foreign lawyer, i.e. a lawyer established in another Member State. Unlike Directives 2005/36 and 98/5, Directive 77/249 does not allow migrant lawyers to be fully integrated in the host Member State, i.e. to become a lawyer using the professional title of that Member State.

12 See Article 17(4) of Directive 2006/123.

13 Maastricht University/Panteia Study, pp. $64-66$.

14 See judgment of 9 March 2017, Piringer, C-342/15, EU:C:2017:196, paragraphs 40, 41 and 44.

15 For further details see Articles 2, 3 and 7 of Directive 77/249. 
As the Court stated, Directive 77/249 does not expressly define what is covered by the term 'lawyer's activity' within its meaning. However, by the definition of 'lawyer', the EU legislature left it to the Member States to define that notion themselves and referred to the designations used in each Member State to identify the persons entitled to pursue those professional activities. In other words, the EU legislature wished to preserve the power of the Member States to define activities that may be pursued by lawyers by leaving them with a broad margin of discretion in that regard. The notion of 'lawyer's activity' within the meaning of that directive covers not only the legal services typically provided by lawyers, such as legal advice or representing and defending a client in court, but may also cover other kinds of services, such as the authentication of signatures; the fact that those latter services are not provided by lawyers in all Member States being of no relevance in that respect. To the extent to which it seeks to facilitate the effective exercise by lawyers of the freedom to provide services, Directive 77/249 must be interpreted as applying both in the typical case of the lawyer travelling to a Member State other than that in which he or she is established in order to provide his or her services and in the case where that professional does not travel, namely where it is the recipient of the service who travels outside his or her Member State of residence in order to visit another Member State and to avail of the services of a lawyer established there. ${ }^{16}$

\section{RESPECT OF RULES OF PROFESSIONAL CONDUCT}

Activities relating to the representation of a client in legal proceedings or before public authorities must be pursued in each host Member State under the conditions laid down for lawyers established in that State, with the exception of any conditions requiring residence, or registration with a professional organization, in that State. A lawyer pursuing these activities must observe the rules of professional conduct of the host Member State, without prejudice to his obligations in the Member State from which he comes. ${ }^{17}$ The term 'without prejudice' simply means that in case of a conflict of rules of professional conduct, the stricter rules will apply. ${ }^{18}$ Therefore, Directive 77/249 introduces duplicity of rules of professional conduct (double deontology, also known as Kumulationsprinzip). ${ }^{19}$

A lawyer pursuing activities other than those listed above remains subject to the conditions and rules of professional conduct of the Member State from which he comes without prejudice to respect for the rules, whatever their source, which govern the profession in the host Member State, especially those concerning the incompatibility of the exercise of the activities of a lawyer with the exercise of other activities in that State, professional secrecy, relations with other lawyers, the prohibition on the same lawyer acting for parties with mutually conflicting interests, and publicity. The latter rules are applicable only if they are capable of being observed by a lawyer who is not established in the host Member State and to the extent to which their observance is objectively justified to ensure, in that State, the proper exercise of a lawyer's activities, the standing of the profession and respect for the rules concerning incompatibility.

16 See judgment of 9 March 2017, Piringer, C-342/15, EU:C:2017:196, paragraphs 28 - 30, 31 and 36.

17 See Article 4 of Directive 77/249.

18 SISKIND, G., Freedom of Movement for Lawyers in the New Europe. In The International Lawyer, Vol. 26, No. 4 (1992), pp. 899 - 931, at p. 916.

19 See CLAESSENS, S. Free Movement of Lawyers in the European Union. Nijmegen : Wolf Legal Publishers, 2008, p. 27. 
In the event of non-compliance with the obligations referred to in Article 4 of Directive 77/249 and in force in the host Member State, the competent authority of the latter must determine in accordance with its own rules and procedures the consequences of such non-compliance, and to this end may obtain any appropriate professional information concerning the person providing services. It must notify the competent authority of the Member State from which the person comes of any decision taken. However, such exchanges do not affect the confidential nature of the information supplied. $^{20}$

It follows that Directive 77/249 distinguishes between two categories of activities: (a) representation of a client in legal proceedings or before public authorities ('judicial activities') and (b) other activities ('extrajudicial activities'). In the case of the first category of activities, migrant lawyers are subject to two sets of rules of professional conduct: both those applicable in the host Member State and the rules of their home Member State. If the lawyers pursue extrajudicial activities, a 'relaxed duplicity of professional rules' applies. Thus, the migrant lawyer remains, in the first place, subject to the rules applicable in his home Member State. At the same time, he must respect the rules applicable in the host Member State (which are included in the non-exhaustive list contained in the Directive), but only to a certain extent defined by the Directive. It follows that Directive 77/249 establishes, in the case of extrajudicial activities, a certain hierarchy in favour of the rules applicable in the home Member State. ${ }^{21}$ In this respect, it must be observed that the term 'representation' is not devoid of ambiguity and the activities regarded as assistance in one Member State may be qualified as representation in another. Therefore, it is for the migrant lawyer to determine the activities that he is entitled to carry out on the basis of the professional title used by lawyers in the host Member State. ${ }^{22}$

As the Court has held, by requiring compliance with the rules relating to professional ethics of the host Member State, Directive 77/249 assumes that the person providing the services has the capacity to comply with those rules. If the competent authority of the host Member State has already found in the course of proceedings concerning access to the legal profession that that person lacks such capacity so that he is barred from access to the profession on that ground, he must be considered not to satisfy the very conditions laid down by the directive with regard to freedom to provide services. Therefore, the provisions of that directive may not be relied upon by a lawyer established in one Member State with a view to pursuing his activities by way of the provision of services in the territory of another Member State where he had been barred from access to the legal profession in the latter Member State for reasons relating to dignity, good repute and integrity. Moreover, a Member State whose legislation requires lawyers to be registered at a bar may prescribe the same requirement for lawyers who come from other Member States and who take advantage of the right of establishment guaranteed by the Treaty in order to establish themselves as members of a legal profession in the territory of the first Member State. ${ }^{23}$

Even though Directive 77/249 establishes duplicity of rules of professional conduct, it does not resolve the issue of conflicts between such rules. Coordination of such rules at the European level seems to be, by far, the best solution. In this respect, the Code of Conduct for European Lawyers

20 See Article 7 of Directive 77/249.

21 See KREMLIS, G. La libre circulation des professions juridiques. In Le droit détablissement et la libre prestation de services dans la Communauté européenne, 1986, p. 109.

22 ROODT, H. C. Harmonisation of the legal profession in the wake of the freedom to practise law in Europe 1992: diversities and commonalities. In The Comparative and International Law Journal of Southern Africa, Vol. 25, No. 2 (1992), pp. $208-231$, at p. 211.

23 See judgment of 19 January 1988, Gullung, 292/86, EU:C:1988:15, paragraphs 21, 22 and 31. 
drawn up by $\mathrm{CCBE}^{24}$ is a very commendable achievement. In fact, the very purpose of that code is to mitigate the difficulties which result from the application of 'double deontology', notably as set out in Articles 4 and 7(2) of Directive 77/249 and Articles 6 and 7 of Directive 98/5. However, that code is not binding in the Member States.

The Maastricht University/Panteia Study identifies the parallel application of the deontology of the home Member State and the host Member State when providing services as an obstacle that can preclude lawyers from providing temporary services and suggests revising the current system of double deontology. The authors of that study claim that that problem could be solved by dismissing the double deontology in favour of a single deontology, i.e. the rules of the home Member State should be applied in the case of temporary services and the rules of the host Member State should apply to established lawyers. ${ }^{25}$ Nonetheless, the CCBE is of the opinion that the only interpretation of Article 4(2) of Directive 77/249 (in the sense of a conflict rule), which is compatible with the wording of that directive, is the same interpretation as adopted on Article 6 of Directive 98/5, i.e. 'in case of a conflict between home and host State professional rules the host Member State's professional rules prevail'. Therefore, the CCBE sees no reason to amend Directive 77/249 with regard to the representation of clients in legal proceedings. ${ }^{26}$ Therefore, irrespective of the suggested dismissal of the double deontology in favour of a single deontology, it can be concluded that in case of a conflict of rules of professional conduct, the rules applicable in the host Member State shall prevail.

Furthermore, it must be pointed out that any Member State may exclude lawyers who are in the salaried employment of a public or private undertaking from pursuing activities relating to the representation of that undertaking in legal proceedings in so far as lawyers established in that State are not permitted to pursue those activities. ${ }^{27}$ However, the wording of this article implies that a salaried lawyer may represent a party who is not the lawyer's employer. Moreover, extrajudicial activities (such as advising a client abroad in the negotiation of a contract) carried out by in-house lawyers are not explicitly regulated, but seem to be accepted, even prior to the adoption of that directive. ${ }^{28}$

Moreover, the Court has held that Directive 77/249 does not preclude a judicial rule of a Member State limiting to the level of the fees which would have resulted from representation by a lawyer established in that State the reimbursement, by an unsuccessful party in a dispute to the successful party, of costs in respect of the services provided by a lawyer established in another Member State. The Court stated that apart from the exceptions expressly mentioned in Article 4 of that directive, all other conditions and rules in force in the host country could apply to the transfrontier provision of services by a lawyer. The reimbursement of the fees of a lawyer established in a Member State may therefore also be made subject to the rules applicable to lawyers established in another Member State. This solution is, moreover, the only one which complies with the principle of predictability, and thus of legal certainty, for a party which enters into proceedings and thus incurs the risk of having to bear the costs of the other party in the event of being unsuccessful. ${ }^{29}$

\footnotetext{
24 Available at <http://ccbe.eu/fileadmin/speciality_distribution/public/documents/DEONTOLOGY/DEON_CoC/ EN_ DEON_CoC.pdf $>$. [q. 2018-05-29].

25 Maastricht University/Panteia Study, p. 230.

26 CCBE, Position on the Evaluation of the Lawyers' Directives, p. 3.

27 See Article 6 of Directive 77/249.

28 SISKIND, G., Freedom of Movement for Lawyers in the New Europe. In The International Lawyer, Vol. 26, No. 4 (1992), pp. 899 - 931, at p. 917.

29 See judgment of 11 December 2003, AMOK, C-289/02, EU:C:2003:669, paragraphs 30 and 31.
} 


\section{$4 \quad$ DUTY TO WORK IN CONJUNCTION}

Article 5 of Directive 77/249 empowers the Member States to require lawyers, for the pursuit of activities relating to the representation of a client in legal proceedings, to be introduced, in accordance with local rules or customs, to the presiding judge and, where appropriate, to the President of the relevant Bar in the host Member State and to work in conjunction with a lawyer who practises before the judicial authority in question and who would, where necessary, be answerable to that authority, or with an 'avoué or 'procuratore' practising before it.

The first duty of lawyers concerning the introduction to the presiding judge or to the President of the relevant Bar in the host Member State is, more or less, a formality. By contrast, the second duty ('duty to work in conjunction') that may be imposed by the host Member State can constitute a real 'burden' for the migrant lawyer. ${ }^{30}$

First and foremost, it must be emphasised that the Court excluded the possibility of a Member State requiring the lawyer providing services to act in conjunction with a lawyer established on its territory if there is no requirement of representation by a lawyer under national law. In fact, Article 5 of Directive 77/249 may not have the effect of imposing upon a lawyer providing services requirements for which there is no equivalent in the professional rules which would apply in the absence of any provision of services within the meaning of the Treaty. ${ }^{31}$

Similarly, in the context of the EEA Agreement, the Court ruled that a provision of national law, according to which, in court proceedings in which a party is represented by a lawyer or a defending counsel must be engaged, a lawyer from another EEA State providing services must call in a national lawyer to act in conjunction with him or her, did not fall under Article 5 of Directive 77/249, referred to at point 2 of Annex VII EEA, and was incompatible with Article 36 EEA and the Directive if it required the appointment of a national lawyer in cases where representation by a lawyer was not mandatory. ${ }^{32}$ It is equally clear from the case-law that the duty to work in conjunction cannot be imposed for the pursuit of activities before bodies or authorities which have no judicial function. ${ }^{33}$

The Court has also held that the refusal, on the part of the competent authorities of a Member State, to issue a router for access to the private virtual network for lawyers to a lawyer duly registered at a Bar of another Member State, for the sole reason that that lawyer is not registered at a Bar of the first Member State, in which he wishes to practise his profession as a free provider of services, in situations where the obligation to work in conjunction with another lawyer is not imposed by law, constitutes a restriction on the freedom to provide services under Article 4 of Directive 77/249, read in the light of Article 56 TFEU and the third paragraph of Article 57 TFEU. ${ }^{34}$

More specifically, it follows from the case-law ${ }^{35}$ that, whilst Directive 77/249 allows national legislation to require a lawyer providing services to work in conjunction with a local lawyer, it is intended to make it possible for the former to carry out the tasks entrusted to him by his client, whilst at the same time having due regard for the proper administration of justice. Seen from that

30 See KREMLIS, G. La libre circulation des professions juridiques. In Le droit détablissement et la libre prestation de services dans la Communauté européenne, 1986, p. 109.

31 See judgment of 25 February 1988, Commission v Germany, 427/85, EU:C:1988:98, paragraphs 13 and 46.

32 See judgment of 3 October 2007, Criminal proceedings against A, E-1/07, OJ 2008 C 17, p. 13.

33 See judgment of 10 July 1991, Commission v France, C-294/89, EU:C:1991:302, paragraph 16.

34 Judgment of 18 May 2017, Lahorgue, C-99/16, EU:C:2017:391, paragraph 42.

35 Judgment of 25 February 1988, Commission v Germany, 427/85, EU:C:1988:98, paragraphs 23 - 26. 
viewpoint, the obligation imposed upon him to act in conjunction with a local lawyer is intended to provide him with the support necessary to enable him to act within a judicial system different from that to which he is accustomed and to assure the judicial authority concerned that the lawyer providing services actually has that support and is thus in a position fully to comply with the procedural and ethical rules that apply. Accordingly, the lawyer providing services and the local lawyer, both being subject to the ethical rules applicable in the host Member State, must be regarded as being capable, in compliance with those ethical rules and in the exercise of their professional independence, of agreeing upon a form of cooperation appropriate to their client's instructions. That does not mean that national legislatures cannot lay down a general framework for cooperation between the two lawyers. However, the resultant obligations must not be disproportionate in relation to the objectives of the duty to work in conjunction.

In the particular context of the German legal system, the Court ruled that the presence of the German lawyer throughout the oral proceedings nor the requirement that the German lawyer must himself be the authorised representative or defending counsel nor the detailed provisions concerning proof of work in conjunction were in general necessary or even useful for the provision of the support required by the lawyer providing services. The same applied to the provision of German law stipulating that a lawyer providing services may not, as defending counsel, visit a person in custody unless accompanied by the German lawyer with whom he is working in conjunction, and cannot correspond with a person held in custody except through that German lawyer, without any exception being allowed. ${ }^{36}$

The Court also dealt with the question whether lawyers providing services under Directive $77 / 249$ may be subject to the rule of territorial exclusivity, which allows lawyers in the host Member State to practise only in certain geographical areas and imposes a duty to work in conjunction with another lawyer outside their own area. The Court concluded that the rule of territorial exclusivity could not be applied to activities of a temporary nature pursued by lawyers established in other Member States, since the conditions of law and fact which applied to those lawyers were not in that respect comparable to those applicable to lawyers established on German territory. ${ }^{37}$ However, this finding only applied subject to the obligation of the lawyer providing services to work in conjunction with a lawyer admitted to practise before the judicial authority in question.

In the context of the French legal system, the Court held that France could not require a lawyer providing services who appeared before a Tribunal de Grande Instance, in civil cases where it was compulsory to be represented by a lawyer, to retain a lawyer who was a member of the Bar of that court or was authorised to plead before it in order to plead or carry out the procedural formalities. Modern methods of transport and telecommunications enable lawyers to maintain the necessary contacts with clients and the judicial authorities and the aim of expeditious conduct of the proceedings could be achieved by requiring the lawyer providing services to have an address for service at the chambers of the lawyer in conjunction with whom he works, where notifications from the judicial authority in question could be duly served. Although the Court recognised that he rule of territorial exclusivity could facilitate disciplinary proceedings against the local lawyer, it held that such a rule was not necessary for the conduct of such proceedings. ${ }^{38}$

Ibid., paragraph 32 .

Ibid., paragraphs $42-43$.

38 See judgment of 10 July 1991, Commission v France, C-294/89, EU:C:1991:302, paragraphs 35 - 37. 
Furthermore, the Court has held that Directive 77/249 precludes a judicial rule of a Member State which provides that the successful party to a dispute, in which that party has been represented by a lawyer established in another Member State, cannot recover from the unsuccessful party, in addition to the fees of that lawyer, the fees of a lawyer practising before the court seized of the dispute who, under the national legislation in question, was required to work in conjunction with the first lawyer. ${ }^{39}$

\section{CONCLUSION}

Those lawyers who do not seek integration into the legal profession of the host Member State and immediate establishment under the professional title of that State may benefit from Directive 77/249. Even though Directive 2005/36 has introduced a simplified mechanism for providing services, that mechanism does not apply to lawyers and the provision of services by lawyers is still governed by the former directive, which has proved to be a true success and managed to ensure a full mutual recognition of lawyers providing services in the EU. In fact, that directive has been of great help in transforming the idea of unhampered cross-border provision of services by lawyers in the EU into a common reality. It is not based on mutual recognition of professional qualifications of lawyers, but on automatic recognition of lawyers recognised as such in their Member States of origin. Thus, a migrant lawyer provides services in the host Member State under the professional title of his home Member State and continues to be bound by the rules of professional conduct of that latter State, alongside the rules applicable in the host Member State.

One of the major problems raised by Directive 77/249 is the application of that principle of double deontology coupled with the distinction between judicial and extrajudicial established by that directive, in particular in case of a conflict of rules of professional conduct.

It has been argued above that such a conflict could be resolved by applying (i) the stricter rule, irrespective of its origin, or (ii) the rule of the host Member State, or by (iii) dismissing the double deontology in favour of a single deontology, which means that the rules of the home Member State should always be applied in the case of temporary services. It has been concluded that, irrespective of the suggested dismissal of the double deontology in favour of a single deontology, which may seem more straightforward, but perhaps not entirely justified, as the law stands, in case of a conflict of rules of professional conduct, the rules applicable in the host Member State must prevail.

Another serious problem encountered by lawyers providing cross-border services relates to the application of the duty to work in conjunction with a local lawyer in the host Member State. However, that problem has already been, to a large extent, solved by the Court's case-law, which has, in particular, excluded the possibility of a Member State requiring the lawyer providing services to act in conjunction with a lawyer established on its territory if there is no requirement of representation by a lawyer under national law as well as the application of the rule of territorial exclusivity to activities of a temporary nature pursued by lawyers established in other Member States.

39 See judgment of 11 December 2003, AMOK, C-289/02, EU:C:2003:669, paragraph 41. 


\section{Bibliography:}

CCBE position, Evaluation of the Lawyers' Directives. Available at <http://ccbe.eu/fileadmin/speciality_distribution/ public/documents/FREE_MOVEMENT_OF_LAWYERS/FML_Position_papers/EN_FML_20140912_CCBE_ position_on_Evaluation_of_the_Lawyers_Directives.pdf >. [q. 2018-05-29].

CLAESSENS, S. et al. Evaluation of the Legal Framework for the Free Movement of Lawyers, Final Report. Zoetermeer : Maastricht University/Panteia, 2012.

CLAESSENS, S. Free Movement of Lawyers in the European Union. Nijmegen : Wolf Legal Publishers, 2008.

DWORKIN, R. Taking rights seriously. Cambridge Mass : Harvard University Press, 1978.

KREMLIS, G. La libre circulation des professions juridiques. In Le droit détablissement et la libre prestation de services dans la Communauté européenne, 1986.

ROODT, H. C. Harmonisation of the legal profession in the wake of the freedom to practise law in Europe 1992: diversities and commonalities. In The Comparative and International Law Journal of Southern Africa, Vol. 25, No. 2 (1992), pp. 208 - 231.

SISKIND, G. Freedom of Movement for Lawyers in the New Europe. In The International Lawyer, Vol. 26, No. 4 (1992), pp. $899-931$.

\section{Contact information:}

doc. JUDr. PhDr. Ing. Michael Siman, PhD., D.E.A.

michael.siman@paneurouni.com

Faculty of Law, Pan-European University in Bratislava

Tomášikova 20

82102 Bratislava

Slovakia 